\title{
近世初期三輪山における禁足の制定とその景観 神社の禁足地とその景観に関する研究 \\ ESTABLISHMENT OF THE TABOOS AND ITS LANDSCAPE IN MOUNT MIWA OF THE EARLY MODERN ERA
}

On the tabooed land in shrine and its landscape

是澤紀子*

\section{Noriko KORESAWA}

\begin{abstract}
Focusing on the early modern era when the "taboos" were established, this paper is to clarify the characteristics of landscape in shrine created by the tabooed land of Mt. Miwa from the perspective of the surrounding mountain forest, and landscapes in picture maps. At the same time as the major development of the Ōmiwa shrine in the Kanbun era (1661-73), taboos were established behind "Mitsu-Torii", and the area was classified as "Miwa Myojin Main Shrine Mountain". It shows that in that setting, from 1638 there was a view towards "Tomeyama" or the total protection of the entire mountain as, which at the same time was overlapping with a view towards the partial protection. Here we can see the condition of a multi-layered protection taking the shape, and already such an area could be seen in picture maps drawn before the establishment of the taboos.
\end{abstract}

Keywords : Landscape, Shrine, Tabooed land, Mount Miwa, Early modern era 景観，神社，禁足地，三輪山，近世初期

\section{1.はじめに}

寺社の景観は、自然環境の保全と密接なかかわりをもっている。 たとえば神社本殿の周囲に保全された状態にある自然林注1）が、現 在、地域の潜在自然植生を示寸指標となっているものも少なくない 注 2)。これらの自然環境は、信仰にまつわる精神的な機能や、自然 林の育成を伴う生態学的な機能を保つだけではなく、立地や規模に よっては樹木の利用など社会経済的な機能を保持している注3)。

このような神社と自然環境との関係を具現しているものの一つと して、山を御神体としてまつる神社の景観があると考えられる。と くに奈良県の大神神社、長野県の諏訪神社上社本宮、埼玉県の金鑽 神社などが知られ、これらは御神体をまつる本殿をもたず、山麓の 拝殿から、御神体である山そのものを遥拝する形式をとる。その代 表的な神社である大神神社では、古代には御諸（三諸・御室）山、 三諸の神奈備（名備・名火）山、神岳、神山とも呼ばれた三輪山が 御神体とされてきたことは著名であり注4)、これを遥拝する形式で 大物主神を祀っている。この大神神社抳殿の背後にある三ツ鳥居よ り奥に山の中腹にかけて広がっている土地が「禁足地」である。

本来、「禁足」は外出を禁じることであるが、「禁足地」とは、神 社の境内あるいは祭神ゆかりの地で特に神聖視され、人の出入りが 禁止される土地のことを指す注 5)。その典型的な事例の一つが大神 神社の「禁足地」で、三輪山が有する多数の谷のうち、三ツ鳥居よ り後方の大宮谷の一帯に位置する。「禁足地」という用語は比較的新
しく注6)、この領域を巡っては近世から近代にかけて、山林の管理 や大規模な社殿の造営、祭祀遺跡の発見や遺物の出土等に留まらず 注 7)、明治初期の社寺領上知を契機とした環境整備等に応じながら、 その時々で山と神社との関係のもと解䣋され、「禁足地」を示寸用語 も変化を伴い、位置づけられてきた售8)。しかしながら、先行研究 にみる「禁足地」は、「神体山」という用語の成立過程において「神 体」と関連付けられた用語の一つとして取り上げて論じたものであ り、「禁足地」そのものに焦点をあてて、その位置づけを絵図史料と の相関から捉えることによって、「禁足」の制定にかかわる景観の特 質を考察することが可能と考えられる。

これまでに三輪山を対象とした景観の研究は、麓に広がる地域か らの眺望や、そこでの街道及び水系等から立地の構造を読み解くも のであり注 9)、三輪山を眺める視点に立った視覚的な景観の研究が 主体であった。さらに、三輪山を描いた絵図史料の分析に関しては、 景山春樹氏による論考注 10$)$ があるものの、他は建築史学分野の建 築物の描写分析が中心であり注11)、これまでに「禁足地」にある山 林の景観を含めた詳細な分析はなされていない。

従って、本研究では「禁足」が制定された近世初期に焦点をあて て、「禁足」の制定とその背景を探り、中世から近世にかけて描かれ た絵図にみる景観との相関を捉えることによって、「禁足」の制定に かかわる景観の特質を明らかにすることを目的とする。とくに「禁 足」の制定には寛文年中の訴訟が契機となったことが神道学の分野

\footnotetext{
* 名古屋工業大学大学院工学研究科 准教授 ·博士 (工学)

Assistant Prof., Graduate School of Eng., Nagoya Institute of Technology, Dr. Eng.
} 
で指摘されており注 12 、 、これを踏まえて本研究では「禁足」制定の 背景を捉えた上で、絵図との相関から景観の特質を探る。また、山 林の景観については、京都近郊の山地を主とした絵図の描写分析に よる研究が蓄積されており注 13 )、これらの手法を参照しつつ「禁足 地」にかかわる絵図の描写分析を試みたい。

絵図にみる景観には、現実の景観に対するひとつの解釈が表現さ れているものと考えられる。ここに「禁足」がもたらした景観の特 質が見出されるとするならば、景観の変化やそれが依拠してきた性 質の一端を理解することが可能であろう。そうした変化が依拠する 性質こそ、景観を継承していく上で指針になるものと考えられる。

\section{2.「禁足」の制定とその範囲一三三輪明神本社山の成立}

寛文六年（1666）、奈良奉行の土屋忠次郎より神社に達せられた 『三輪山禁足牓示定書』注 14 ）により、三輪山における「禁足」が 定められている。これが以後の「禁足地」を示す時の根拠となるも のであり、そこには次のように記されている。

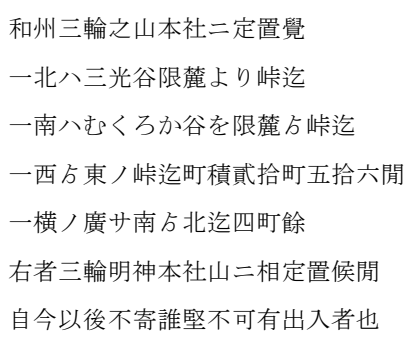

三輪神主

これより、「三輪之山本社」において、人の出入りを禁止する範囲 を「三輪明神本社山」として定めたことがわかる。その範囲は、北は 「三光谷」、南は「むくろか谷」の「麓」から「趾」までを境とし、 南北の幅は「四町餘（約 $436 \mathrm{~m}$ )」注 15 )、東西の奥行きは「東ノ峠」 まで「戴拾町五拾六閒 (約 $2,283 \mathrm{~m}$ )」とある。この史料について『神 道大系』には「三輪山が禁足地としてあがめられたことを示寸史料 のひとつ」注 16) とあるように、山全体の捉え方と重ねて取り上げ た例もあるが、史料上に記された範囲はあくまでも三輪山の一部分 を示したものであり、三輪山とは区別した「三輪明神本社山」とい う名称まで付している。その範囲をみると、谷や峠などの地形に依 拠した記述によって限定している。

ここで示された範囲について、現在の「禁足地」より広域であっ たことが指摘されているが注 17 )、具体的に検証するため、明治 41 年測図の地形図に、『大神神社史』注 18 8) の附図「三輪山全景（平面 図)」に示された現在の「禁足地」の範囲と、周辺の谷の名称とを重 ね合わせたものが図 1 である。これをもとに寛文六年に制定された 範囲と現在の「禁足地」の範囲とを比べてみると、「東ノ峠」まで二 キロ余という数值は大きいことに気づく。このことから「三輪明神 本社山」の範囲は、図 1 の「三光谷」と「ムクロ谷」を境として、 山頂に向かって広域であった可能性がうかがえる。

以上にみた地形に依拠した境界は、実際、三ツ鳥居が位置する西 側に関しても、過去の地理的環境において同様であったことが発掘 調査により明らかにされている。すなわち、現在の扯殿がある平坦 地は一二世紀以降に造成されたもので、それ以前は、二つの川の流 れに挟まれた微高地と、その前面の扇状地が形成する中洲のような

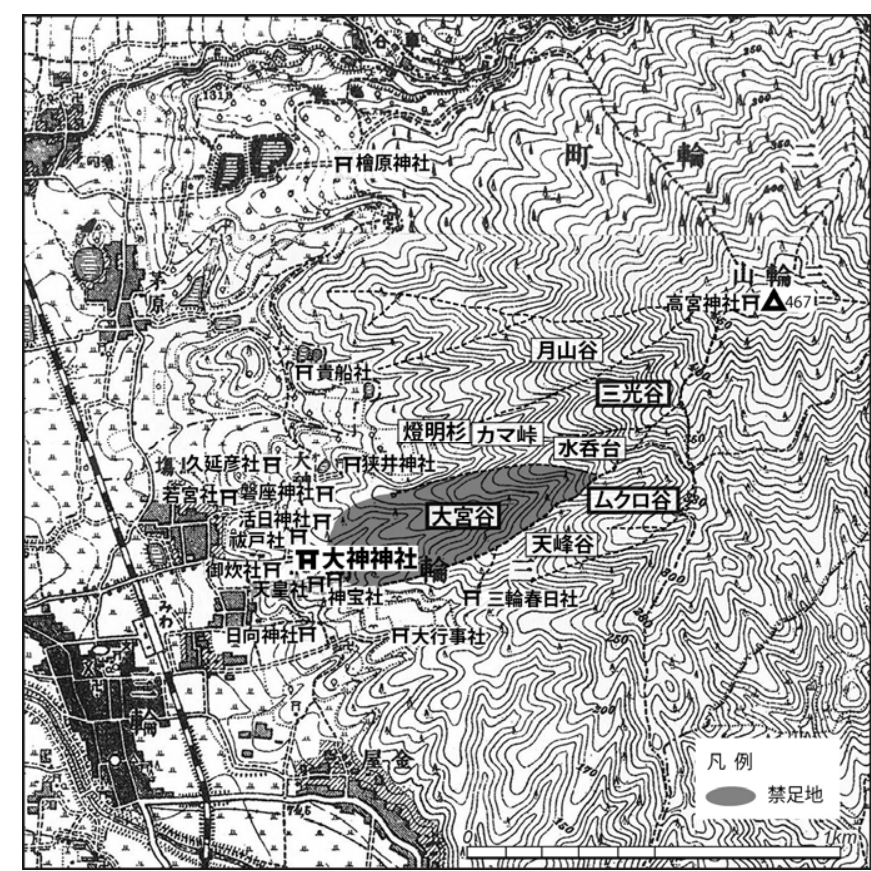

図 1 三輪山における大神神社及び禁足地概略位置図

状態にあったことが判明した注19)。このことから自然の微高地であ る「禁足」の範囲を介して、人工的な造成地である扯殿から三輪山 を遥拝していることがわかる。ここに「禁足」が制定された範囲に もとづく領域は、三輪山を遥拝する拝殿及び三ツ鳥居の後方という 位置づけよりも、むしろその前面に山を遥择する施設があるという 位置づけが見受けられるのである。

\section{3、「禁足」制定の背景一『寛文中高宮越両家訴訟覚書』の検討から}

「禁足」を定めた寬文期は、择殿の再建を含めた大規模な整備が 行われた時期であった。現在の拝殿は、棟札より寛文四年（1664） 三月に上棟したことが知られている。扯殿の造営に関しては、越家 蔵の『享保中大神社覚書』注20)によると、文保元年（1317）の造 営の後、度重なる修復があり、さらに文禄二年（1593）の修復を経 て、寛文三年に再び造営が実施された。そのうち寛文造営について は、越家蔵の『寛文中高宮越両家訴訟覚書』（以下、『覚書』）注2 1) のなかに「三輪御社御造營入用請取拂目録」として拝領金二千両の 使途明細が記されており、拝殿のほか大鳥居、二ノ鳥居など中心的 な施設が整備されたことが読み取れ、とくに拝殿に関する記述をみ ると「百五拾目 古拜殿こわし申手間二拂」とある。以上から、旧 扯殿を取壊して建替えたことがうかがえる。したがって、拝殿再建 を含めた建造物群の整備と同時期に、「禁足」が制定された範囲にも とづく領域は明確化されたことが確認できる。

この頃、寛文四年（1664）七月に社家の高宮右京に対して、同じ 社家の越半兵衛が起した訴訟があったことに留意したい。その内容 は、社殿の造営方針にくわえ、余った資材や古木の処理から三輪山 の神木や下草刚などの環境管理にまで及ぶもので、相互の書状が先 の『覚書』に記録されている。両家が江戸一下り、寺社奉行の井上 河内守と加々爪甲斐守とによる裁断を仰いだ経過がわかるものであ る。この訴訟では、高宮右京の死去と一時延引によって両家は帰国 するが、翌年の三月に再度江戸へ下り、七月にようやく決着をみる。 
両者の主張は「山」と「樹」に対寸る異なる視点から展開している が、三輪山の山林に対する共通認識として、『莊嚴組記録』をみると 既に慶長一六年（1611）には、氏子から代官一宛てた「山之儀御願 之願書」注 2 2) に以下の記述がある。

（前略）むのしょり仕つけ申候間、千年之通す゚ず仕候、就其山之法度 仕者無御座候は〉、御山きりあらし可申と存、山回加け申候、其給をも鄉 中方仕宛、社家衩き神子は急んり上仕、一里究もいたし不申事（後略） このように社家等が山の「きりあらし」を懸念していたことを氏子 が報告している。さらに、寛文四年（1664）五月には高宮家の「三 輪神主起請文」注 23$)$ として以下の記述がある。

三輪山之義御赦免二付、神配共大宮、若宮御供柴、神主列火柴、神前御 供所、神主屋敷道橋用木之外毛頭壱本二而も伐採申間敷候（後略）

これより、限定しつつも三輪山の樹木は伐採すべきではないことが 表明されている。以上より、三輪山を保護すべきとの観念は、社家 や氏子が共有していたことがうかがえる。したがって『覚書』は、 これを記録し所蔵した越家の主張であることを考慮してもなお、こ れを期に「樹」が神体とされたとの指摘もあるように注 24$) 、 三$ 輪山 の山林に対する当時の視点を探る上で看過できないと考えられる。

『覚書』の史料のうち、まずは越半兵衛が訴えた内容を示した「乍 恐書付を以申上候事」から、山林に対する記述の部分を見てみよう。

卞輪大明神者御神體二樹刍奉崇候處、中坊美作殿より薪札を拾枚申請候

而、鄉人二札を賣渡シ申候、尤落葉をかきとり申定二御座候へとも、落 葉計にては無御座候、其子細へ先年も此度御造営御訴訟之路銀遣銀之た め神木之落葉をかき、下草をかり申札拾枚中坊美作殿占申請、方々鄉人 二賣付申候故、下草二まじ急御神禾壳萬本餘切取申候（後略、傍点筆者） このように「樹」そのものを「御神體」として崇め奉る視点が「三 輪大明神者御神體二樹习奉崇候處」との記述に表れている。同時に、 そこでは「神木」の落葉掻きや下草刈り、さらには切取まであった と主張しているが、ここでの「神木」とは「下草にまじ总御神木壱 萬本餘切取申候」とあるように過度のスケールで表現していること からも、特定の「樹」やその場所を限ったものではなく、三輪山に 育成する「樹」を広く捉えていたものといえよう。

これに応じて高宮右京が返答した「御裏書帱見仕返答之篠々」に は、以下のように記されている。

卞輪大明神は山を甞㐫奉方事勿論三候、いにしへへ十三ヶ村之氏子共、 落葉下苅なと猥取申候故山荒申候、就共飛騨守殿御吟味被成留山三成候、 然共鄉人忍々山木を伐取申候故私方より山まはりを申付候、我等勝手不 自由二御座候故、山まはり給分己下二悉迷惑仕、中坊美作守殿へ御斷を 申、落葉之札拾枚出シ申候、又大山みて御座候へへ、雪折風折又は末留 りの木などをば、或八神前之道橋或々御祈念之時の松明、御神事の用事 大宮御供所、大御輪寺並神主別火柴等之儀は、獸な之方方さ文所を薪に 仕候故、神前三か⿱丶万仙まき所を、先規より取遣ひ申候、(中略) 近年 事外生茂り、春日山同前深山と罷成候事顕然之処、伐荒し申候とは偽成 申事二候、仰願へ令為立 御検使を御覧被下候へへしれ申御事二候 (後 略、傍点筆者)

これより、三輪山の樹木の売買を否定するにあたって、まず「山」 を崇め奉る視点を主張していることがわかる。ただ『覚書』の全体 を通してみても、「樹」とは異なり「山」を「御神體」あるいは「神 體」とした表現が見当たらないことは看過できない注25)。これを受 けて、越半兵衛が提出した書状「高宮右京返答書之旨二對シ乍恐口
上書を以申上候篠々」をみると、

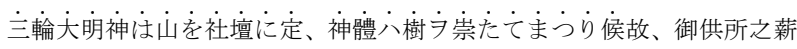
柴々霜枯之落葉をひろひ焼申候作法にて御座候、(中略) 御公儀様山中 出出之禁制之御札御立被窟成候故山中出出之一圓無御座候處二、右京山 廻り之給分と名付賣札を申請、方々一賣渡シ申二付、商買物之故只今八 おそれ亦く山をあらし申候、(中略)、明神之御ためニ八山をあらし申大 敵二て御座候間、彼右京退治被営成賣札も急度被召上可被下候（後略、 傍点筆者

とあり、山は「社壇」、すなわち神を奉ったところであり、山ではな く樹木を「神體」に見立てる視点が改めて強調されていることを確 認しておきたい。

ここで注目すべきは、これらの訴訟文のなかで寛永一五年 (1638) に奈良町奉行の中防飛彈より神社に達せられた『寛永中中坊飛彈守 之制札』注 26）を引き合いに出していることである。その全文は以 下の通りである。

三輪山制札之事

定

一三輪山林拜木葉市み捕もの於有之者、手前うち捨たるべき事、

一當山奶人の風聞於有之八、いずれの在々所々まても爲神主遂穿鏫此方 几可申屆事、

一山ぬす人於告知者同類たりとゆふとも、其科をゆるし爲隹美銀子拾枚可 遺事、

右篠々堅可相守者也、

宽永十五年卯月日

中坊飛彈（在判）

これは三輪山を対象とした保護制札であり、越半兵衛の書状にある 「御公儀様山中一出入禁制之御札御立被爲成候故山中一出入一圓無 御座候處」との記述はこのことを示している。とくに高宮右京によ る返答書には「いにしへへ十三ヶ村之氏子共、落葉下苅なと猥取申 候故山荒申候、就共飛騨守殿御今今味被成留山二成候」とあり、「十三 ヶ村之氏子共」の利用によって山が荒れたことにより制札が達せら れ、これを期に公的に三輪山全体を「留山」、寸なわち住民の狩猟や 樹木の伐採が禁じられた山林としてきたことがわかる。同時に、程 度こそ不明であるが、寛永期には山林が荒廃しつつあるとの認識で あったことがうかがえるのである。

山林が荒廃する背景には、住民側が自然の恩恵を享受するなかで、 神主側による利用と管理の模索が続いていた。住民側に対しては、 後の享保一八年 $(1733)$ に近村の 185 名が連署した『三輪山近村人 連判請書』注 27$)$ によって、松茸の密採取を禁じている。一方、神 主側では先の訴訟文にある高宮右京の返答書をみると、手を加えな い部分を配慮しつつ、「獸なとけかさぬ所」や「神前ニかまひなき所」 を利用してきた姿勢が読み取れる。ここで配慮されてきた部分と現 在の「禁足地」との関連は不明であるが、「留山」のように樹木の伐 採等が禁じられることによる山林の保護を全体保護として捉えた場 合に、手を加えない部分のみを配慮する行為は部分保護として捉え られる。このことから三輪山では「留山」という全体保護の視点に、 神主側と住民側による利用を背景とした部分保護への視点が重なっ ていったことが読み取れ、ここに、重層的な保護の領域が形成され ていく前提がうかがえる。

この訴訟が終結した寛文五年の七月に寺社奉行より達せられた 
「三輪山御式目」の内容は『覚書』に記されている。それをみると、

三輪山之儀八他所相替由緒有之由二候篠、立榜示之うち之一二圓可窟不

之、其外みて下草落葉等札を相渡候者共可取之、猥二山へ不入様二神主 以下社人中科若宮別當平等寺等堅可相防之事（後略、傍点筆者）

とあり、「榜示」を立てて区分し、その内部は「不入」とすることが 示されていることから、この訴訟が翌年の「禁足」制定の契機とな ったことは明らかである。ただ、「禁足」が制定される以前の景観が 描かれた絵図をみると、三ツ鳥居の後方に、三輪山全体とは異なる 領域の表現がうかがえるのである。次章では、それら二枚の絵図を 取り上げて、後世に描かれた絵図との比較をしつつ、現在の「禁足 地」にあたる三ツ鳥居の後方が、どのような景観として描かれてい たのかを検討したい。

\section{4. 絵図にみる「禁足」制定前の景観}

\section{(1)「三輪山絵図」に描かれた景観}

まず、三輪山を描いた絵図のなかで最もよく知られているのが、 室町から桃山時代の制作と考えられている「三輪山絵図」(図 2 ) で ある注 28$)$ 。現在は大神神社が所蔵する絵図で、これを納めた箱の表 書に「三輪山繪圖箱 惣什物三輪山平等寺」とあることから、神宮 寺であった平等寺に伝来したものであることが知られ、この年代に ついては諸説みられる。『大神神社史』には室町時代と紹介されてお り、景山春樹氏の論考注29) では桃山時代の制作とされているが、 その根拠は示されていない。絵図を収納した箱の蓋裏には「享保一 六（1731）年亥年八月吉日大智院宥信代栫之」とあるが、景山氏は これを絵図とは別に箱が寄進された由の書きつけであるとしている。 なお、本絵図の模本と考えられている絵図がいくつか存在する。そ れらの絵図には文政一三（1830）年に「中川春闌」が記したと書か れており、「三百餘年以前之圖」である平等院伝来の古図を写したも のであることが記載されている。このことから原本は、室町時代後 期には存在していた説が生じたとの指摘がある注 30 )。さらに、櫻井 敏雄氏は絵図の「紙質はかなり新しく、手法等による時代考証もさ れておらず、正確なところはなお不明」であることから「享保一六 年を遡りうる絵図」とした上で、描写内容からは「室町時代の内容 を復興の目的で筆写しなおしたと考えるのが妥当」と結論づけてい る。試みに、この絵図の描写内容について他の絵図と比較してみる

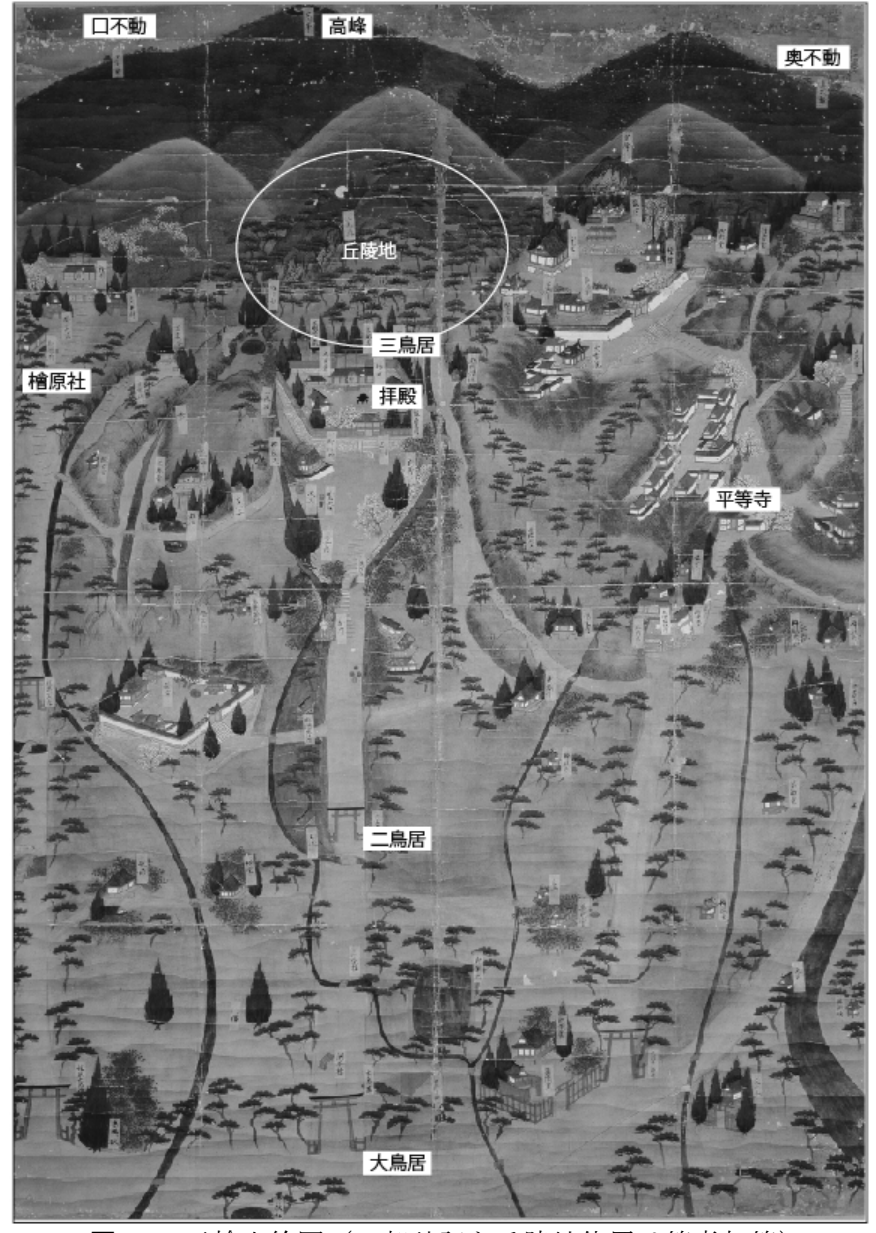

図2 三輪山絵図（一部註記と丘陵地位置は筆者加筆）

と (表 1 )、以下のことがわかる。三ツ鳥居奥の「大般若経蔵」や扯 殿前方にある「大日屋」「護摩所」山中の「三光瀧」「星下 (降) 」 のように、正保二年（1645）の記文がある「三輪社絵図」と「三輪 山絵図」には共通する描写があり、それらは江戸時代に制作された 絵図をみると摸本以外は描かれていない。また、絵図に描かれた「大 般若経蔵」「大日屋」「護摩所」は、先述の『享保中大神社覚書』に 列記された施設一覧にはなく、また享保一八年 (1733) から元文年 中（1736-41）の記録『御修復願書並一切書付控』注 3 1) にもない。

表1 三輪山の絵図にみる山容と点景の描写

\begin{tabular}{|c|c|c|c|c|c|c|c|c|c|c|c|c|c|c|c|c|c|c|c|c|c|c|c|c|c|c|c|c|c|c|}
\hline \multirow[b]{4}{*}{ No. } & \multirow{4}{*}{ 古絵図名称 } & \multirow[b]{4}{*}{ 所 蔵 } & \multirow{4}{*}{ 年 代 } & \multirow{4}{*}{ 山容描写 } & \multicolumn{26}{|c|}{ 主な点景（O描写有／註記有，口描写有／註記無） } \\
\hline & & & & & \multirow{2}{*}{\multicolumn{13}{|c|}{$\begin{array}{l}\frac{\text { 建造物 }}{\text { 楼門奥 }} \\
\end{array}$}} & & & & \multirow{2}{*}{ 滝岩 } & & \multicolumn{6}{|c|}{\begin{tabular}{l|l} 
独立樹 \\
擙
\end{tabular}} & \multicolumn{2}{|c|}{ 霊石 } \\
\hline & & & & & & & & & & & & & & & & & & \multicolumn{3}{|c|}{ 娄門前 } & & & & & & & & & & \\
\hline & & & & & $\begin{array}{l}\text { 高 } \\
\text { 宮 }\end{array}$ & $\begin{array}{l}\text { 般 } \\
\text { 蕗蔵 }\end{array}$ & 蔵 & $\begin{array}{l}\text { 淮 } \\
\text { 堂 }\end{array}$ & 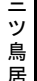 & & 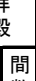 & $\begin{array}{l}\text { 昌 } \\
\text { 屋 }\end{array}$ & 薪 & 使 & 家 & 呬 & 䉍 & 供 & 鳥 & & $\begin{array}{l}\text { 光 } \\
\text { 瀧 }\end{array}$ & 降 & 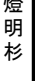 & 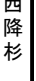 & 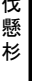 & 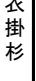 & 杉 & $\begin{array}{c}\text { 本 } \\
\text { 杉 }\end{array}$ & $\begin{array}{l}\text { 琹 } \\
\text { 石 }\end{array}$ & \\
\hline & & & & & & & & & & & 好 & & & & & & & & & & & & & & & & & & & \\
\hline 1 & 三輪山絵図 & (平等寺旧藏) & 推定 & 三峰 & O & O & 0 & - & 우 & O & 5 & 인 & 0 & $\square$ & $\square$ & - & O & 인 & 이교 & 0 & 이 & 이 & 인 & - & - & 이 & - & 0 & O & 0 \\
\hline 2 & 三輪社絵図 & 大神神社 & 正保二年 (1645) & 独立峰 & $\mathrm{O}$ & - & 0 & O & O & O & 9 & - & - & O & 이 & -1 & O & 이 & 이 & O & 이 & 이 & 0 & -1 & 미 & 미 & $\square$ & $\square$ & - & - \\
\hline 3 & 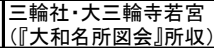 & - & $\begin{array}{l}\text { 寛政三年 (1791) } \\
\text { 行 }\end{array}$ & 独立峰 & - & - & - & - & 미 & O & 7 & - & - & O & 이 & - & ㅁ & ※ & $\square$ & $\square$ & -1 & -1 & - & 미 & O & 이 & O & O & O※ & \\
\hline 4 & \begin{tabular}{|l|} 
輪山古図(『三輪叢 \\
\end{tabular} & 大神神社 & $\begin{array}{l}\text { 㐫政一三年(1830) } \\
\text { 玟 }\end{array}$ & 独立峰 & O & O & O & - & 이 & 0 & 9 & 이 & O & 0 & O & -1 & 미 & 이 & o & O & 이 & 이 & 0 & - & - & 이 & 二 & 0 & 이 & 0 \\
\hline 5 & 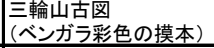 & 大神神社 & $\begin{array}{l}\text { 文政一三年(1830) } \\
\text { 記文 }\end{array}$ & 独立峰 & 0 & O & 0 & - & O & O & 5 & O & 이 & O & O & - & O & 이 & 이 & O & 이 & 이 & O & -1 & 二 & 이 & - & O & 이 & $\mathrm{O}$ \\
\hline 6 & 大和国三輪神社図 & 宮内庁 & 慶応四年 (1868) & 独立峰 & 0 & - & 0 & - & O & $\square$ & 7 & - & - & O & 이 & - & 마 & 이 & ㅁ & $\square$ & - & -1 & O & 미 & O & 이 & O & O & - & - \\
\hline 7 & $\begin{array}{l}\text { 和州三輪大明神絵図 } \\
\text { (摸本) }\end{array}$ & 大神神社 & $\begin{array}{l}\text { 江戸時代 } \\
\text { 推定 }\end{array}$ & 独立峰 & 0 & ※3 & 0 & - & O & O & 5 & - & - & 0 & 이 & 0 & O & 이 & 이 & 0 & 이 & 이 & ㅁ & -1 & 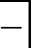 & O & - & O & -1 & - \\
\hline 8 & 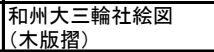 & 大神神社 & $\begin{array}{l}\text { 江戸時代 } \\
\text { 推定 }\end{array}$ & 独立峰 & 0 & - & 0 & - & O & 0 & 5 & - & - & O & 이 & -1 & - & 이 & $\square$ & O & -1 & -1 & O & 이 & O & 이 & O & O & - & - \\
\hline 9 & 大和国三輪神社之図 & $\begin{array}{l}\text { 天理大学图書館 } \\
\text { 吉田文庫 }\end{array}$ & 江戸時㫿定 & 独立峰 & 0 & - & 0 & - & 이 & 0 & 5 & - & - & O & 이 & - & 0 & 이 & 이 & O & -1 & -1 & 0 & -1 & O & 이 & 이 & 0 & - & - \\
\hline
\end{tabular}

※1「社家」と註記。 ※2「夫婦石」と註記。 $※ 3$ 大般若経蔵の位置にある建造物に「一夜酒宮」と註記. 


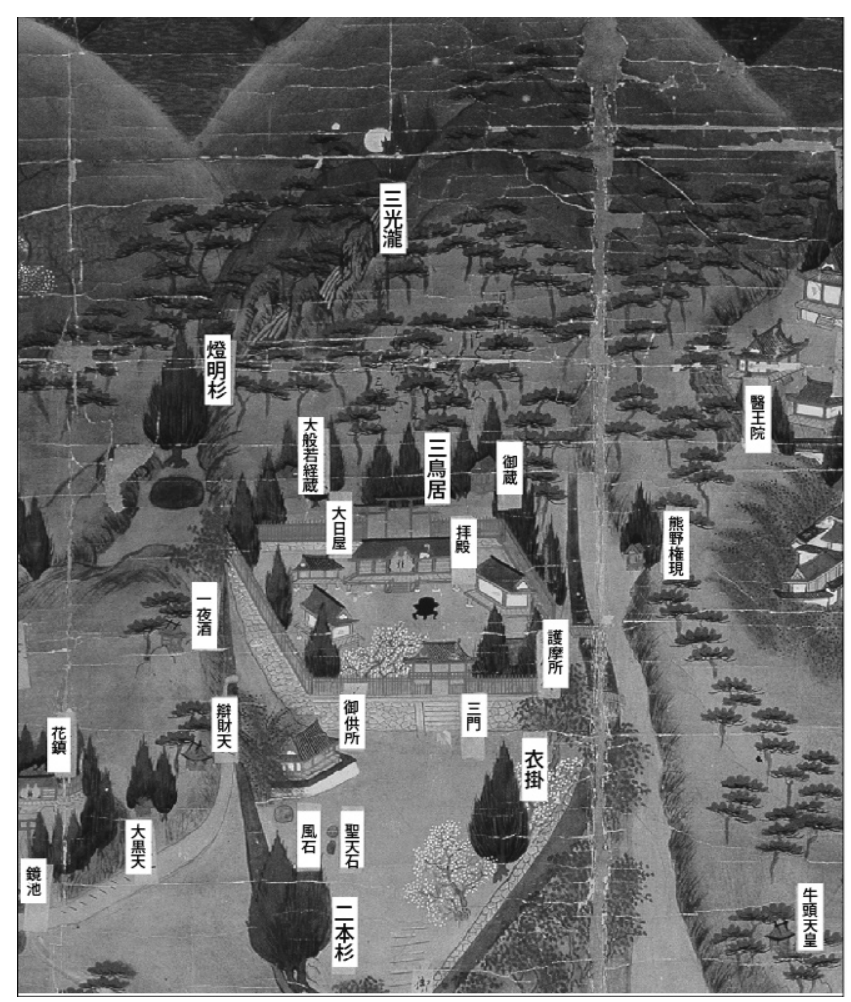

図3 三輪山絵図（部分に筆者加筆）にみる点景と樹種の描写

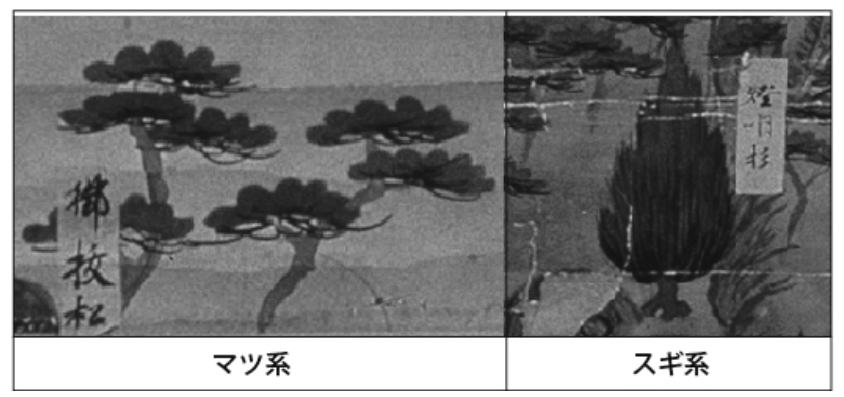

図4三輪山絵図（部分）にみる各樹種の描写

くわえて、『享保中大神社覚書』にあるように、寛文以降には修理の

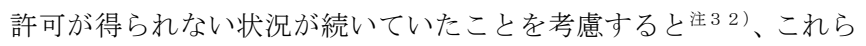
の建物は寛文以前に存在したものと考えられる。したがって、「三輪 山絵図」は寛文以前の景観を示した絵図とみることは妥当であろう。 改めて「三輪山絵図」をみると、鮮やかな彩色が施されており、 瓦莫の屋根が、檜皮莫や板亘等の屋根とは描き分けられている様子 も見受けられる。画面の構成は、中央に描かれた大神神社を中心と して、北（左）に「檜原社」、南（右）に「平等寺」が配され、各々 の寺社に至る三筋の参道が伸びている。三輪山の山容は、これらの 各寺社と対応するように三つの峰に分けて描かれ、中央には現在の 高宮神社にあたる「高峰」、左峰には「口不動」、右峰には「奥不動」 と註記された祠が見える。このような連峰の描写は、摸本を含めた 他の絵図をみると (表 1)、それらがすべて独立峰の三輪山の姿で描 かれたことと極めて対照的である。ここでとくに留意したいのは、 大神神社の三ツ鳥居後方には、一層青々とした丘陵地が描かれてい ることである。これまでに絵図の制作時には、山に対する観念より も拝殿の辺りや神宮寺伽藍など後世の施設に視点が定められ、それ らを詳細に描いていることが指摘されてきた注 3 3)。ただ、その描写 をみると、大鳥居や参道のほか、各施設や玉垣周辺に描かれた樹木
と同じような精度で、三ツ鳥居の背後や後方の丘陵地一帯において 樹木が描かれていることは看過できない（図 3 )。

そこでの樹種の描写に着目してみると、註記のある「燈明杉」や 「二本杉」、「衣掛（杉）」に見られるような枝が上に伸びるスギ系の 描写とは異なり、三ツ鳥居後方の丘陵地一帯では、枝を横に張るマ ツ系の描写による樹木に覆われている注 34 )。この絵図では、図 4 に 示寸ように押紙ではあるものの樹種がわかる註記がみられ、大鳥居 の西（下）に「御拔松」、三ツ鳥居の北（左）に「燈明杉」の描写が 確認できる。したがって、この絵図ではスギ系とマツ系の樹木が描 き分けられていることは明らかである。

とりわけスギ系の樹木は、註記のある大木のみならず、大神神社 の三ツ鳥居背後や玉垣に沿って、また摂社狭井社にあたる「花鎮 (社)」などの周囲に、そして「三光瀧」の滝口などにも描かれてい ることから、マツ系の樹木以上に特定の場所を際立たせるランドマ ークとしての配置が読み取れる。このような配置は、三ツ鳥居の背 後や、その両脇に描かれた「大般若経蔵」及び「御蔵」の背後にあ るスギ系の樹木にも見受けられる。これらの描写からは、建造物群 による神社の創出と一体的となって、それらの背後にスギ系の樹木 が育成されるための一つの動機が推察できるのである。

こうしたスギ系の樹木に対して、マツ系の樹木は、参道の並木や 摂社活日神社にあたる「一夜酒（社）」などの小規模な神社の脇、そ して三ツ鳥居後方の丘陵地一帯に描かれており、その密度は丘陵地 一帯に至るほど高く描かれていることがうかがえる。三ツ鳥居後方 の丘陵地一帯は、さらに後方にある三輪山全体とは明らかに異なる 描写であることから、山全体とは区別した領域として捉えられてい たものと考えられるのである。その領域をみると「三光瀧」までを 取り込んでいることから、現在の「禁足地」よりも広域であり、そ こに描かれていたのはマツ系の樹木であった。

\section{（2）「三輪社絵図」に描かれた景観}

次に、寛文六年（1666）より前に制作されたと考えられるもう一 つの絵図をみてみよう。「正保貮年（1645）九月廿四日」との記文 がある「三輪社絵図」（図５）である注３５）。絵図の下方には、三輪 社の「大明神」にくわえて神宮寺の「平等寺」や「若宮大御輪寺」 による三つの寺社領の記文があるが、絵図の描写をみると、「平等寺」 や「若宮大御輪寺」のほか「社家屋」や「大門」「灌頂堂」は単に位 置を示す表現に留まっている。その理由として、寛文造営の直前と いう絵図年代を考慮すれば「零落もしくは倒壊していた建物」であ ったか、とくに二つの神宮寺に関しては三輪社を主として描写した 絵図であることから「省略した性格の図」とも捉えられることが指 摘されている注 36$)$ 。確かに一部を簡略化した絵図に見受けられる一 方で、表 1 に示すとおり他の絵図と比較してみると、三輪社に関す る主な点景はほぼ全て描かれていることに留意したい。

ここで、「三輪社絵図」に描かれた樹種の描写に着目してみると、 註記のある樹木は「花鎮（社）」近くに描かれた「燈明杴」（図 6) のみであるが、これと同様のスギ系の大木の描写が参道から拝殿に 至るまでにいくつか確認できる。このような註記のないスギ系の大 木について、表 1 の他の絵図に描かれた註記のある樹木とその位置 を比較検討した。その結果、「三輪社絵図」では「社家屋」の西に「切 伐（掛）杉」、「御供所」の西に「二本杉」、「勅屋」の西に「衣掛杉」 と「門杉」を描いていることが判明した。 


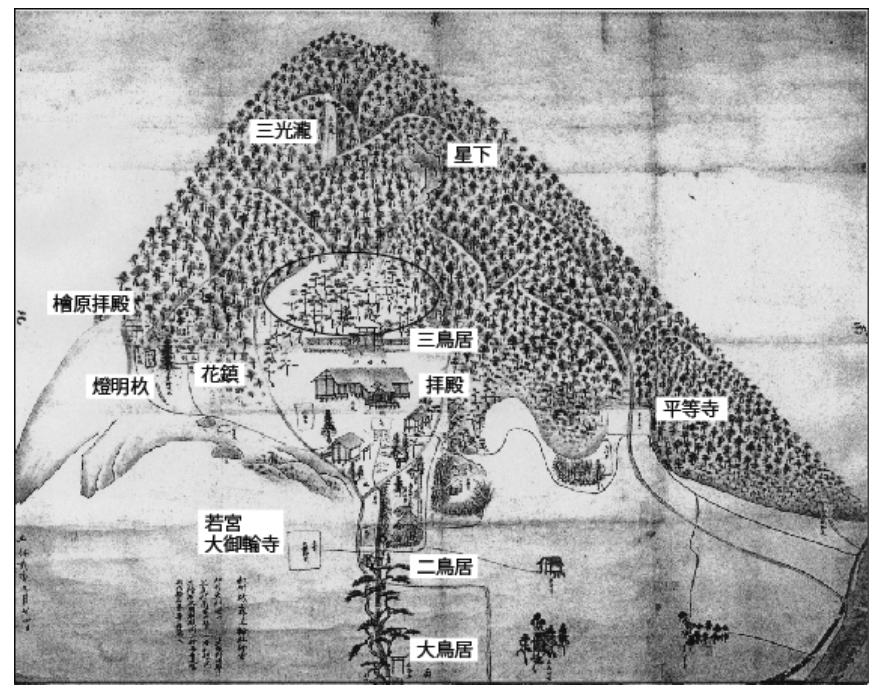

図5 三輪社絵図（筆者加筆）にみる点景と樹種の描写

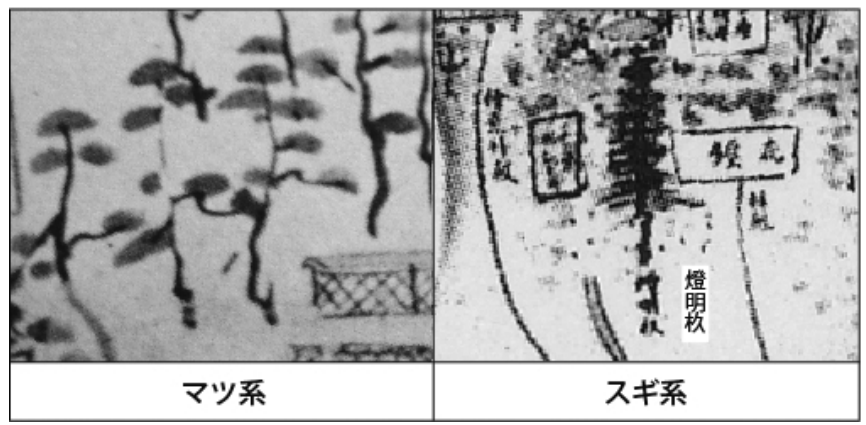

図6 三輪社絵図（部分に筆者加筆）にみる各樹種の描写

一方で、このような点景としてのスギ系の樹木とは明らかに異な り、枝を横に張るマツ系の樹木が、参道の「大鳥居」から「二鳥居」 にかけて、また三ツ鳥居後方の区域に描かれていることは注目す心゙ きである。それらは山全体を覆っている樹木の描写とも異なる。す なわち、「三輪社絵図」でも「三輪山絵図」と同様に、三ツ鳥居の後 方の描写が山全体の描写とは異なるのである。このことから、三ッ 鳥居の後方が山全体とは区別した領域として捉えられていたものと 考えられる。さらに絵図の彩色をみると、「大鳥居」から「二鳥居」 にかけては幹の赤いマツ系の樹木が一際大きく描かれていることに 対して、三ツ鳥居後方の領域では幹の黒いマツ系の樹木が描かれて いる。これがアカマツやクロマツといった相違を表現したとは考え 難いが注37)、三ツ鳥居後方の領域が、他とは区別して描かれている 様相が絵図の彩色からもうかがえる。

ここで三ツ鳥居の後方に描かれた領域をみると、「三光瀧」までは 遠く及ばず、「三輪山絵図」よりも小規模な領域として描かれている ことが判る。またこの絵図には「三輪山絵図」の三ツ鳥居背後や玉 垣に沿って描かれたスギ系の樹木の描写は見出せない。

以上、「禁足」を制定した寛文六年（1666）以前の景観を描いた 「三輪山絵図」と「三輪社絵図」における三ッ鳥居後方の描写につ いて分析した結果、いずれも三輪山全体とは異なる描写の領域があ ることを明らかにした。さらに、その規模こそ異なるが、領域一帯 に描かれているのはマツ系の樹木であったことを指摘した。

補足として、「禁足」の制定と同じ年に編まれた地誌『和州寺社記』 には「社壇なく杴村を以て本社と崇め奉る」注38) と記されている
ように、古来、スギに着目した記述が散見される一方で、近代以降 の植生調查によると、三輪山の主要林は春日山原始林のような林相 ではなく、数百年内外の第二次的なアカマツ林であることを指摘し ておきたい注39)。すなわち三輪山のアカマツ林は、植生遷移を考慮 すれば、森林破壞によって樹木が伐採された後に繁茂した第二次林 である可能性もうかがえるのである注 40 ）。このような山全体の植生 に対して、とりわけ「禁足地」一帯では周辺からの観察によってス ギ・ヒノキ・アカマツ・ネズの針葉樹の他、ツブラジイ・アカガシ 等の暖地性常緑広葉樹に富むことが示されている。そこでの過去の 植生を検証するためには、今後さらなる調查により科学的分析を踏 まえた見解が得られることに期待したい。

\section{5. まとめ}

三輪山の神社景観の特質について、「禁足」が制定された近世初期 に焦点をあてて、背景にある山林への視点と絵図に描かれた景観と を重㸚合わせて検討した結果、以下のような知見が得られた。

拝殿の再建を伴う大規模な整備が行われた寛文期 (1661-73)に、 三ッ鳥居の後方では「三輪明神本社山」として「禁足」が制定され たことによって、その範囲にもとづく領域が明確化された。ここで 「禁足」が制定された範囲をみると、現在の「禁足地」よりも山頂 に向かって広域であったと考えられる。

「禁足」が制定された背景として、『寛文中高宮越両家訴訟覚書』 の検討から、三輪山では、すでに寛永一五年 (1638) の制札により、 山林が荒廃しつつあるとの認識のもと、山全体を「留山」とする保 護体制を整えていた一方で、こうした全体保護の視点に対して、神 主側と住民側による利用を背景とした部分保護への視点が重なって いったことが読み取れた。ここに、重層的な保護の領域が形成され ていく前提がうかがえる。

そのような重層的な領域は、すでに「禁足」の制定以前の様子を 描いた「三輪山絵図」と「三輪社絵図」にみることができる。それ らにはいずれも三ツ鳥居の後方に、三輪山全体とは異なる描写の領 域があることから、「禁足」の制定以前より、重層的な保護の領域が 形成されつつあった可能性がうかがえるのである。両絵図ではその 領域の規模こそ異なるものの、そこにはいずれもマツ系の樹木が描 かれていることを指摘した。

すなわち、「禁足」の制定は、「留山」という三輪山の全体保護を 前提とした、「三輪明神本社山」としての部分保護でありながら、保 護の在り方としては部分が全体を象徵する領域として位置づけられ ていったものと考えられる。

\section{附記}

本研究に際して、調查にご配慮をいただいた大神神社並びに同主任研究員の 山田浩之氏に感謝の意を表する。なお、本研究は科学研究費補助金 (若手研 究（B）課題番号 24760518 ・研究代表者：是澤紀子）の成果の一部である。

\section{参考文献}

1) 神道大系編纂会編: 神道大系 神社編 12 大神・石上, 神道大系編纂会, 1989

2）大神神社史料編修委員会編：大神神社史料 第一巻 史料編，大神神社史 料編修委員会, 1968

3）大神神社史料編修委員会編 : 大神神社史料 第二巻 史料編（続）他六篇, 大神神社史料編修委員会, 1974

4）大神神社史料編修委員会編：大神神社史料 第八巻 続拾遺篇 坤，大神神 
社史料編修委員会, 1981

5）大神神社史料編修委員会編：大神神社史，大神神社社務所，1975

6）大神神社社務所編：三輪叢書, 大神神社社務所, 1927

7）大三輪町史編集委員会編 : 大三輪町史, 大三輪町，1959

8）桜井市史編纂委員会編：桜井市史 史料編 上巻，桜井市役所，1981

9）奈良県立橿原考古学研究所編：大神神社境内地発掘調查報告書 防災工 事に伴う調査，大神神社，1984

10) 平成の大造営記念竣成誌編纂委員会編 : 大神神社平成の大造営竣成誌 上 巻, 大神神社, 2001

11）和田萃編：大神と石上 神体山と禁足地，筑摩書房，1988

12）山田浩之：「神体山」の成立一近世二輪山観の展開, 神道宗教, 151, pp52-77, 1993

13）大場磐雄：まつり一考古学から探る日本古代の祭，学生社，1967

14) 景山春樹: 大三輪神社古繪圖について, 神道史研究, 9 (6), pp203-216, 1961

15）樋口淸之：三輪山上に於ける巨石群，考古學研究， 1, pp59-70, 1927

16）樋口淸之: 大神神社の考古學的研究, 神道史研究, 9 (6), pp58-70, 1961

17) 樋口清之: 三輪山, 神道考古学講座 第五巻, 雄山閣, pp.139-161, 1972

18）樋口忠彦: 景観の構造-ランドスケープとしての日本の構造, 技報堂, 1975

19）嘉名光市：主要眺望点における三輪山の代表的形象に関する研究，都市 計画別冊，都市計画論文集，37，pp.979-984，2002

20）池田秀範・山崎寿一：大和三輪山周辺地域における景観構成一信仰空間 の立地と水系、古街道との関係から, 日本建築学会大会学術講演梗概集 E-2, pp.437-438，2008

21) 小椋純一：絵図から読み解く人と景観の歷史，雄山閣，1992

22）小椋純一：古写真と絵図類の考察からみた鎮守の杜の歴史, 国立歴史民 俗博物館研究報告, $148, p p .380-412,2008$

23）是澤紀子・田中稲子・堀越哲美：景観としての神社にみる自然環境保全 の在り方一京都府文化財環境保全地区を事例として，日本建築学会環境 系論文集，No. 598，pp.65-70，2005.12

24）松村義敏：三輪山植物目録，神山保護調査會， 1928

25）緑地研究会編: 森林 社寺林の研究, 1, 土井林学振興会, pp.47-50, 1974

\section{注}

注 1）森林の状態が変化する過程を自然に任せている森林の総称とする。

注 2）植物生態学者の宮脇昭氏は、日本の潜在自然植生を把握するにあたり

「鎮守の森」に着目した。宮脇昭他『鎮守の森』(新潮社、2000)など。

注 3）参考文献 23 。

注 4）参考文献 $1 、 13$

注 5）薗田稔・橋本政宣編『神道史大辞典』(吉川弘文館、2004)、項目「禁足地」。

注 6）典型的な事例として、大神神社と並び称される石上神宮の「禁足地」

があるものの、それらの在り方はきわめて対照的である。すなわち大神神 社では、本来、三輪山という自然の山を聖域とした「禁足地」であること に対して、石上神宮の「禁足地」は、東西にのびる丘陵の北斜面を人工的 に造成した平坦地にあり、布留川が流れる北側を背景として拝殿の奥に位 置している。いずれも拝殿から「禁足地」を拝む形式であったが、石上神 宮では大正二年に「禁足地」内に本殿が建てられたことによって、その形 式が変化した。石上神宮では「禁足地」という呼称が一般化して定まって くるのは江戸時代末から明治時代にかけてのことであり、「禁足」という 記録の初出は元禄一二年（1699）の『石上大明神縁起』である（置田雅昭 「禁足地の成立」、参考文献 11、pp.77-106）。興味深いことに、大神神社 においても近世を通じて「禁足地」という呼称は一般化していない。

注 7）「禁足地」内の古代の祭祀遺跡・遺物として、巨石を神あるいは神の座 とみなした船座の存在や、子持勾玉、滑石製模造品等が知られる。磐座は、 大正末に三輪山中の巨石群を調査した樋口清之氏によって、山頂から西北 西にのびる「オーカミタ二」（玄賓谷）の一群と、大神神社裏の「禁足地」 から尾根上を連ねる一群の巨石群が注目され、それらは分布の標高によっ て、山頂、中腹、山麓の一群がそれぞれ、嘉禄二年（1226）の奥書がある 『大三輪神三社鎮座次第』(参考文献 6 に所収) がいうところの「奥津磐座」、 「中津磐座」、「邊津磐座」にあたることが推定されている（参考文献 15）。 「禁足地」の発掘調查が不可能であることから全貌は不明であるが、樋口氏 によれば、「禁足地」祭祀の起源は、少なくとも前期弥生式文化、二千数 百年以上に遡って考えられるとともに、祭祀の継続は、以後古式土師器や 土製模造品によって古墳時代前期（三〜四世紀）を経て、古墳時代後期（六 〜七世紀の後期土師器、古式須恵器）を通り、奈良時代（八世紀）、平安 時代（一一世紀）に連綿と続き、おそらく平安時代の終わりまで及んだ可 能性が推察されている（参考文献 16）。さらに「禁足地」の巨石は、拝殿 から約 $200 \mathrm{~m}$ 東の方にあり、巨石の下方に石の土留めの跡がか寸かにうか
がえたとの指摘がある（参考文献 17）。

注 8）参考文献 12

注 9）参考文献 18 を端緒とし、現存する景観を眺める視点に立った分析に参 考文献 19、20 がある。

注 10）参考文献 14 。

注 11）建造物の描写から絵図の年代に言及した論考として、櫻井敏雄「(六) 建築」（参考文献 4、pp.787-834）、猪俣規之「平成の大造営第二期工事 扯殿保存修理」（参考文献 10、pp.141-204）がある。

注 12) 参考文献 12 。

注 13）参考文献 21、22 など。

注 14）参考文献 2、pp.589-600。

注 15）一間を $1.818 \mathrm{~m}$ として換算。

注 16）上田正昭「解題」（参考文献 1、pp.5-27）。

注 17）参考文献 14 。

注 18）参考文献 5 。

注 19）参考文献 9 。昭和五八年に実施された大神神社の防災工事に伴う発掘 調査によって、拝殿のある平坦地は一二世紀以降に造成されたものであり、 それ以前には、北側ダイコク谷の活日川と南側オオミワ谷の大宮川という 二つの流れに挟まれた微高地と、その前面の扇状地が形成する中洲のよう な状態にあったことが判明した。このことから、禁足区域の前面には幅 100 $\mathrm{m}$ にわたる砂洲を形成していた状況があり、地理的環境によって境界が形 成されていた様相が窥える。この状況は遺物の発見によって、少なくとも 五世紀まで遡る可能性が指摘されている。

注 20）参考文献 6、pp 177-191

注 21）参考文献 6、pp.297-347。

注 22)『莊嚴組記録』所収慶長一六年五月二四日願書 (参考文献 6、pp.201-202)。 注 23)「三輪神主起請文」（参考文献 8、上巻、p.890)。

注 24）参考文献 12 。

注 25）参考文献 12 には「神体」という表現自体は近世にみられるものの、

三輪山が「神体」であるとの言い方は近世を通じて定着しておらず、明治 以降に三輪山を「神体山」とする表現が成立していくとの指摘がある。

注 26）参考文献 6、pp.672-673。

注 27）参考文献 6、pp.675-680。

注 28）大神神社所蔵。参考文献 3 の「宝物編」に室町時代の絵図として所収。

注 29) 参考文献 14 。

注 30）櫻井敏男「（六）建築」（参考文献 4、pp787-843）。

注 31）参考文献 6、pp. 478-551。

注 32）参考文献 6、pp177-191。「寛文三年より元禄十六年迄、四拾一年二 成也、江戸地震二付、御修覆日延引被仰出、今二御沙汰無之候」とある。 注 33）参考文献 14。また、難波田徹氏は『神社古図集』続編（臨川書店、1990） のなかで絵図の制作年代には触れず、「三輪山の神体山が大きく描かれな い画面構成になったのは、その制作の動機が社殿を中心とした表現を主と したことによると思われる」と解説している。

注 34）絵図に描かれた樹木や樹林等の植物は、その種までを特定することが 難しく、これに対して小椋純一氏は「マツタイプ」「スギタイプ」等いく つかの「タイプ」に分けて考察している（参考文献 21）。本稿では、これ を「マツ系」「スギ系」と表現した。

注 35）大神神社所蔵。図 5 及び図 6 の「スギ系」は参考文献 3 所収の図より筆 者加筆。図 6 の「マツ系」は参考文献 10 所収の部分図より一部転載。

注 36）櫻井敏男「（六）建築」（参考文献 4、pp787-843）。

注 37）「三輪社絵図」ほど明解ではないが、「三輪山絵図」でも参道の並木に幹 が茶色いマツ系の樹木が多く、社殿背後の区域では幹の黒いマツ系の樹木 が中心に描写されている。ただし参道には「網掛の松」と称される目通 3.5 $\mathrm{m}$ のクロマツの古木やその他のクロマツを含む並木が知られることからも (参考文献 7、pp.718-742) 、これらの絵図がアカマツやクロマツを描き分 けていたことは考え難い。

注 38）大和国史会編『大和志』三巻六号（大和国史会、1936）に所収。 注 39）近代以降の植生調査には参考文献 24、25、小清水卓二他「五、植物」 （参考文献 7、pp.718-742）、小清水卓二「三輪山の植物」（参考文献 5、 pp.705-710）がある。

注 40）アカマツ林は貧栄養の土地に生育する樹木である。三輪山の植生を調 査した小清水卓二氏は、ここでのアカマツ林が第二次的な様相を古来より 継承してきたものか、春日山原始林のような林相を呈していたものが天災 あるいは人為によって形成されたものか解決し難いとした（参考文献 5 、 pp.705-710)。 